\title{
パーソナルナビゲーションにおける 位置決め
}

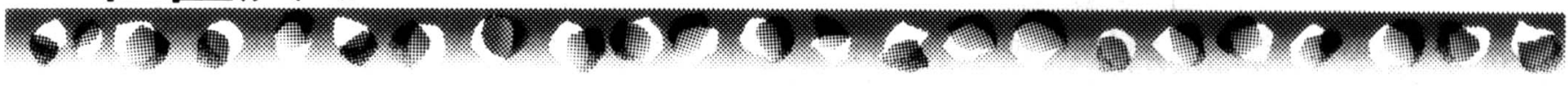

\section{鈴木 昇**}

Positioning in Personal Navigation / Noboru SUZUKI

Key words: positioning, personal navigation, global positioning system, PHS

\section{1. は じめに}

移動する人間等の現在位置を知る（パーソナルナビゲー ションをする) 代表的なシステムに GPS（グローバルポ ジショニングシステム) を用いたものと, PHSを用いた ものがある.

前者の GPS は, 航空機, 船舶, 自動車に広く利用さ れ，自動車では「カーナビゲーションシステム」（カーナ ビ）と呼ばれ，ドライブ，スキー、ゴルフ等に出かける時 に利用されている場合も非常に多く見受けられ，年間 100 万台以上の出荷, 販売がなされている.

一方, 後者の PHS を用いた位置計測システムは専用に 作られた電話機を持っているだけで，他人に自分自身の位 置を知らせることができ，さらに，モバイルコンピュータ と組み合わせることで自分で自分の位置を知ることもでき る. このシステムは, 軽量, 小型で, 位置精度も非常に高 く, PHS 網が完備しているェリアであれば, GPS で使用 できなかった地下街, ビルの中, 地下鉄の駅でも利用でき るものである.

本解説では, PHS を用いた位置測定システムの基本原 理の説明と, システムの一例として, 弊社が開発した $\lceil\mathrm{PHS}$ 位置情報システム」の概要説明を行う.

\section{PHS を用いた位置測定法の原理と精度}

PHS の電話網を利用した位置测定システムは, PHS 電

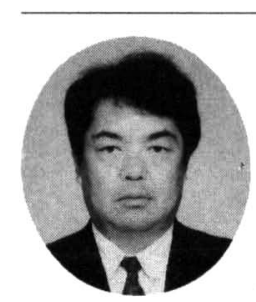

* 原稿受付 平成 11 年 6 月 16 日

** (株)東芝 情報・社会システム社（東京都港区 芝浦 1-1-1)

位置情報システム事業開発部主務
話で利用している基地局（電柱, 公衆電話ボックスに取り 付けられているアンテナ) を利用して位置の測定をする. PHS の位置測定では，1局の基地局を利用した方式と複 数局を利用した測定方式がある. 1 局方式は基地局から発 信された電波を捕まえ, 基地局の電波の飛ぶ範囲にいるこ とを特定する. 基地局から発信される電波は通常 100 150 $\mathrm{m}$ 離れた場所まで届くため, 基地局から半径 $150 \mathrm{~m}$ の円 の中にいることを特定できるだけとなる（半径 $150 \mathrm{~m}$ の 円は東京ドームよりやや大きい面積に相当する (図 1)). さらに郊外に設置されている基地局は強力な電波を飛ばし ているため発信される電波は300～600 $\mathrm{m}$ 近く飛ぶことに なる.これは皇居の広さに相当し, これでは位置検索端末 を持っている人の位置を特定したことにならない.しかし ながら, 1 つの基地局ではなく複数の基地局の電波を使用 し, 各基地局からの距離を計算し位置を特定することによ り, 䜋差数十 $m$ の精度の高い位置測定が可能となる（半 径数十 $\mathrm{m}$ の誤差は東京ドームのグラウンドの大きさに相 当する (図 1)). PHSによる位置測定手法は上記の 2 種 に大きく分けられ, 前者はェリア指定検索として, 個人の 情報検索などに利用されている. 後者は, ピンポイント情 報として, 利用例 (前章) のよらに業務に利用されると考 光られる. また後者の位置情報は精度が高くなることか ら, 個人のプライバシーを侵害しないための配慮（仕組み 作り）も必要になる.

図 2 は測定に使用する基地局数と誤差との関係を示した 図であるが，1局測定は簡単な仕組みで測定できるもの の, 電波の飛ぶ範囲にあることしかわからない. 2 局以上 の測定では, 各基地局から端末むでの距離を求めること で, 測定精度を向上させることができるが，測定した距離 誤差の補正をするために取り込む基地局数を増やすこと で, 測定誤差の補正も可能になる. 次の章で述べる 「PHS 位置情報システム」では, 電界強度を使用し距離を 求め, 距離測定の䛊差を補正するために 5 局の基地局を利 


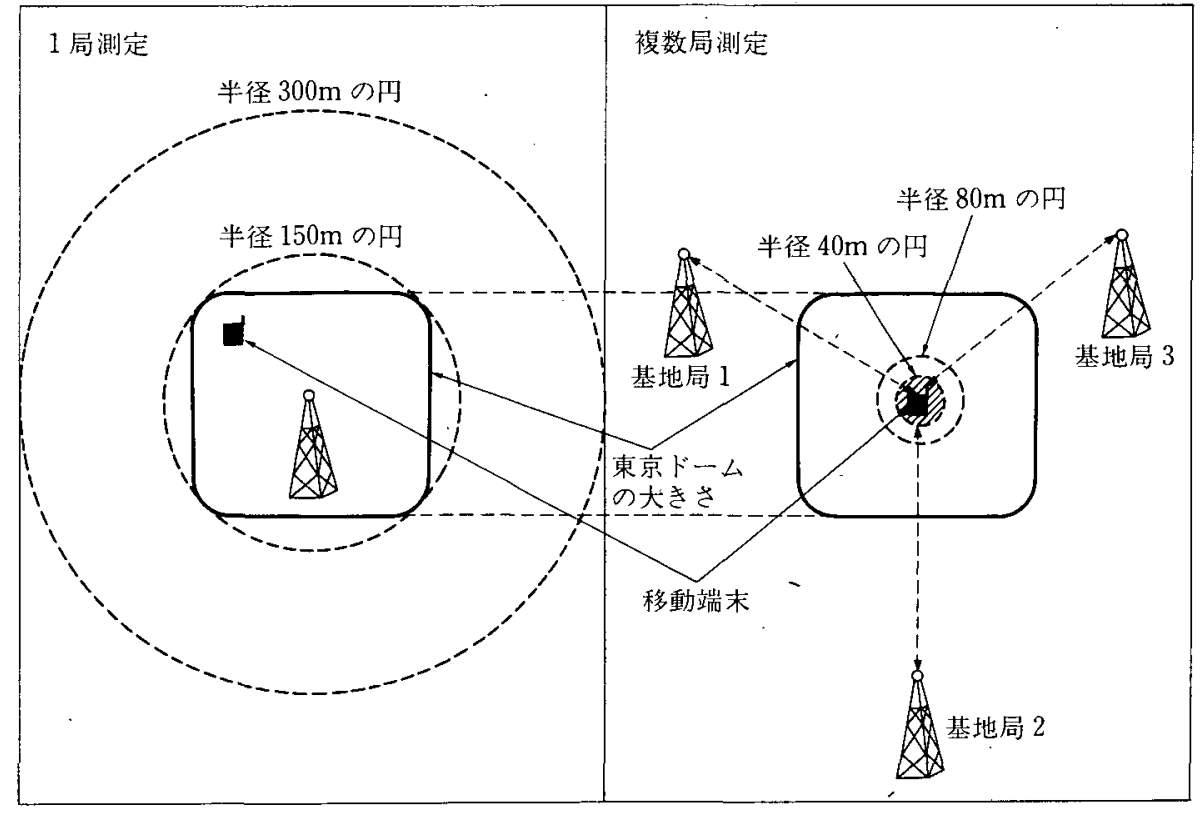

図 11 局测定と複数局測定の比較

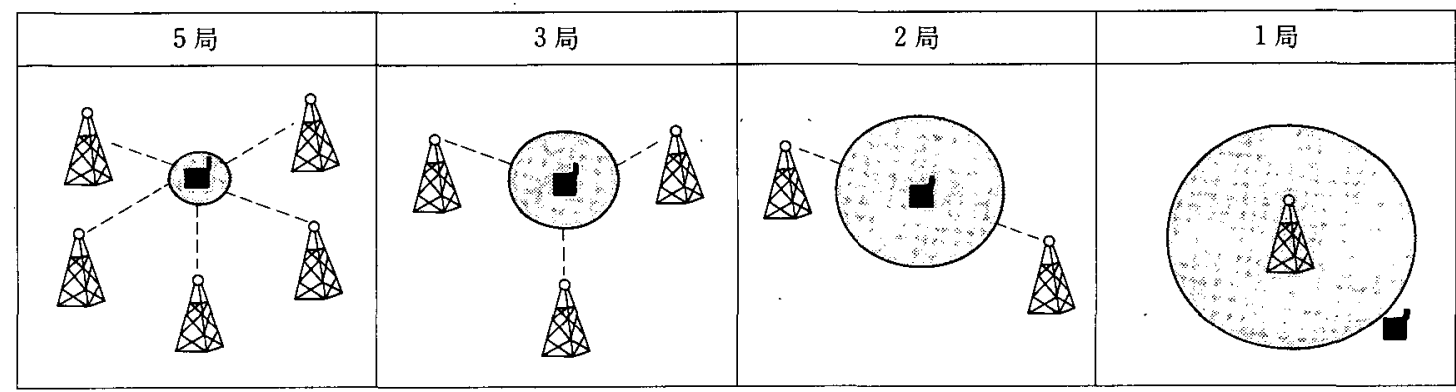

図 2 測定に使用する基地局数による相違

用している。なお，現在 PHSの通信網は人が住んでいる 地域の $90 \%$ 以上をカバーするので，ほとんぞの地域で使 用寸ることが可能になっている.

\section{3.「PHS 位置情報システム」の位置検索方法}

本章では，前章の原理を用いて実際に開発した「PHS 位置情報システム」に和ける位置検索について述べる，検 索は, クライアント PCからのものと移動端末からのあの が存在する.

(a) クライフントPCからの検索

(1) クライアントPCから検索指示を行う.

(2) 位置情報せンターから，公采回線網を経由して指 定されたPHS 端末に位置情報の要求を行う。

（3）要求を受けたPHS 端末は，位置情報データ（基 地局 ID - 電界強度) を複数局分, 位置情報セン ターに送信する。

（4) 位置情報センターは，経度・緯度情報に変換し， クライアント PCに位置情報として返信する。

（b）移動端末からの位置情報連絡

(1) 移動端末に用意されている「位固情報発信ボタ
ン」を押すと，位置情報せンターに電話し，位置 情報データを送信する。

（2）位置情報センターは，受信した位置情報データを 経度・緯度情報に変換し，あらかじめ指定された クライアント PCに位置情報として送信する．位 置情報の送信機能は「位置検索專用端末」で 1 種,「位置検索機能付きPHS端末」で 6 種が用 意されている。

\section{4.「PHS 位置情報システム」の検索の種類と 使用する端末}

次に「PHS 位置情報システム」の検索の種類と使用す る端末について述べる．検索の種類として，下記の検索方 法を実現している（図3）.

(a) クライアントPCからの検索

（1）随時検索

任意に位置情報端末の検索を行りことがでさる.タイ マーを使用したプログラムを作成することで，定期的 （1 分以上）な検索も行うことができる.

（2）追尾検索 


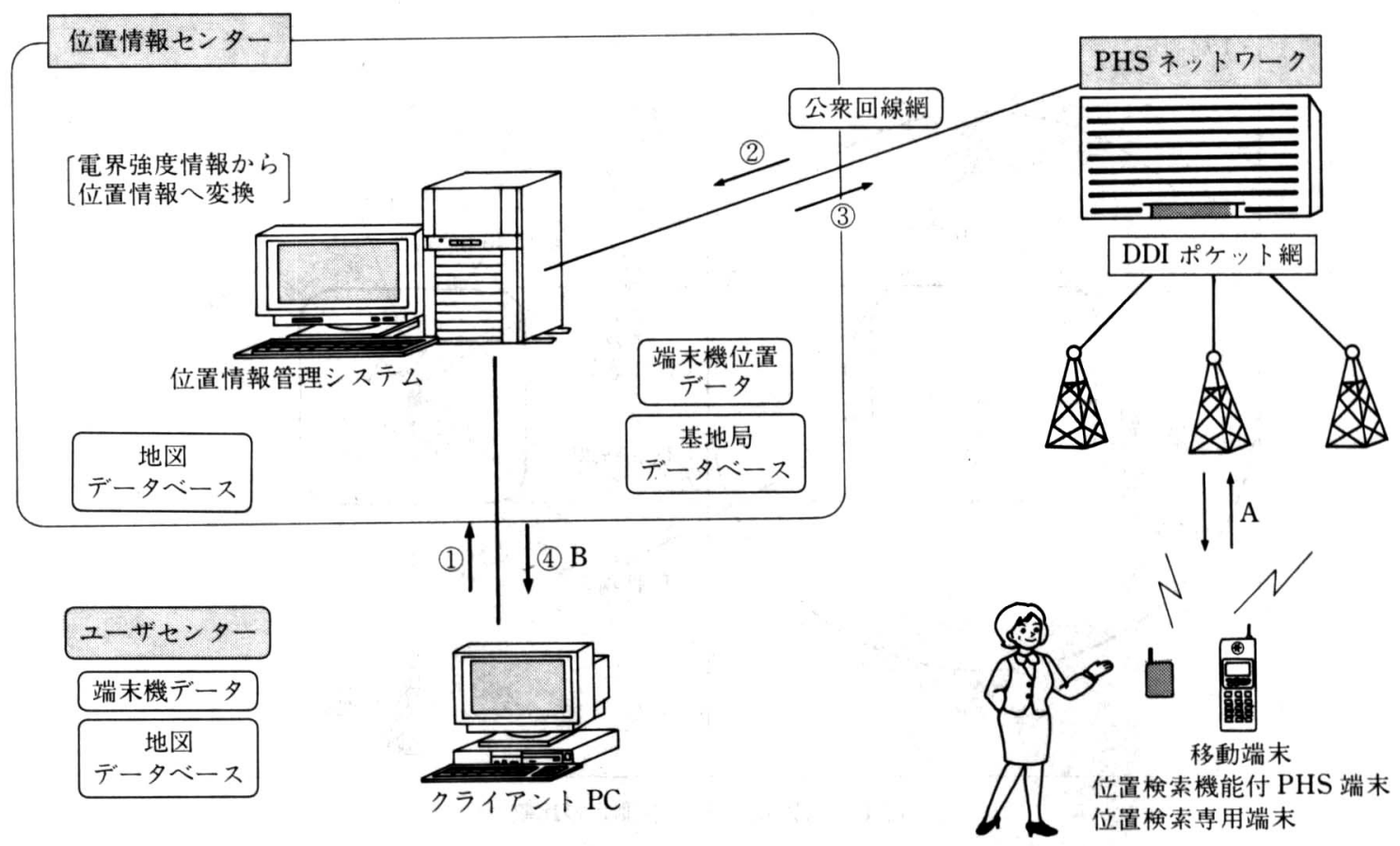

目 3 PHS 位置情報システムの概要

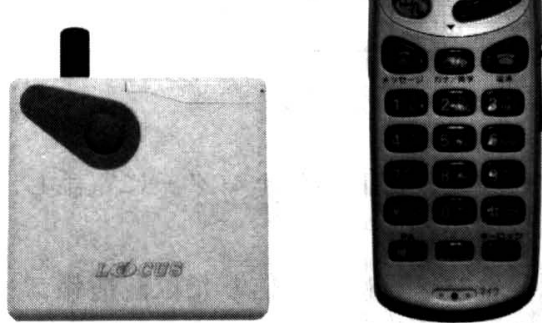

図 4 位置検索専用端末（左）と位置情報希望付き PHS 端末（右）

位置情報端末から連続で位置情報を取得しク ライアント PC に送出する.

(b) PHS 端末からの検索

\section{(1) 緊急発呼}

位置情報端末に用意した「位置情報発呼ボタ ン」を押すことで，センターに位置情報データ を送信する.この機能は, 位置情報専用端末, 位置情報機能付きPHS 端末の両方にサポート されている.

（2）ステータス付き発呼

通話機能付き PHS 端末に用意されている機 能である．緊急発呼の機能にステータス情報を付加する ことができる. ステータス情報は 5 種利用できる.

図 4 に「PHS 位置情報システム」で使用する端末を示 す.
表 1 「PHS 位置情報システム」と GPS の比較

\begin{tabular}{|c|c|c|}
\hline システム名 & PHS 位置情報システム & GPS \\
\hline 接続形態 & $\begin{array}{l}\text { ・端末：PHS データ通信 } \\
\text { ・検索センター：ISDN/(公 } \\
\text { 衆線) }\end{array}$ & $\begin{array}{l}\text { ・航空機, 船舶, 自動車 (カー } \\
\text { ナビ等) }\end{array}$ \\
\hline 対象業務 & $\begin{array}{l}\text {-人, 物の位置検索が可能 } \\
\text { 徘䧃老人探索, 警備業務支 } \\
\text { 援, 荷物位置ほか, 各種検 } \\
\text { 索業務 }\end{array}$ & $\begin{array}{l}\text { ・車両・船舶, 航空機等の位 } \\
\text { 置検索 }\end{array}$ \\
\hline 特 長 & $\begin{array}{l}\text { ・公衆局, 自営局の } 2 \text { 種サー } \\
\text { ピス } \\
\text { ・低コスト } \\
\text { ・高精度 }\end{array}$ & $\begin{array}{l}\text { ・地球上（全世界の海上, 航 } \\
\text { 空, 陸上）の全域で使用可 } \\
\text { 能 } \\
\text { ・上空からの電波が遮断され } \\
\text { る建物内, 地下等では使用 } \\
\text { ができない. }\end{array}$ \\
\hline サービス地域 & $\begin{array}{l}\text { ・通信事業者 (キャリア)の } \\
\text { サービス範囲 }\end{array}$ & - 地球上全域で使用可能 \\
\hline 精 度 & $\begin{array}{l}\text { - } 40 \mathrm{~m} \text { 以内 } 60 \%, 80 \mathrm{~m} \text { 以内 } \\
90 \%\end{array}$ & - 誤差 約 100 200 m 程度 \\
\hline 位置検索機能 & $\begin{array}{l}\text { ・端末, センターどららから } \\
\text { も検索可能 }\end{array}$ & $\begin{array}{l}\text { ・事業者の策定した内容によ } \\
\text { る }\end{array}$ \\
\hline 音声通話 & $\begin{array}{l}\text { - 常時通話可能（通話機能付 } \\
\text { き） }\end{array}$ & - 不可 \\
\hline 動態把握 & $\begin{array}{l}\text { - 歩行速度 }(60 \mathrm{~km} / \mathrm{h} \text { 程度ま } \\
\text { で把握可) }\end{array}$ & • 高速移動中でも把握可能 \\
\hline 備 考 & $\begin{array}{l}\text { ・基地局のある地下街, ビル } \\
\text { の中, 地下鉄のホーム等で } \\
\text { も使用可 }\end{array}$ & $\begin{array}{l}\text { ・建物の陰, 中など衛星から } \\
\text { の電波が届かない所は使用 } \\
\text { 不可 }\end{array}$ \\
\hline
\end{tabular}

\section{PHS を用いたシステムの利用分野}

PHS による位置測定システムを使用した位置検索には 
下記のような用途がある。

1. 人が持ち利用する位置検索

1) 徘䧃老人探索

2) 迷子探索

3）動線分析

4）警備業務支援

5) サービスマン位置把握, 等

2. 物, 動物に取り付けた位置検索

1)レンタカー管理

2）現金・貴重品輪送

3）大型ペット迷子探索

4) 盗難防止

5) 宅配便業務支援，等

このように様々な業務で今後必要となる位置管理に利用 できる。

\section{PHS と GPS との比較}

GPS は年々小型化され，人が持ち歩けるようにした商 品もあるが，測定誤差も大きく，長時間使用できない，地 下鉄等，空の見えない場所での利用ができない等の問題が ある。また GPS は自分の位置を知ることはできるが，他 人の位置を知らせることができない，他人に自分の位置を
知らせるには，別の手段，電話，無線機等と組み合わせ利 用することが必要になるが，この場合は，通信手段の通信 エリアに制限され，広域で使用することが不可能になる.

一方 PHS は地下鉄の駅など地下，ビルの中など位置情 報の取得が可能であるが，位置情報を取得できるエリアに 地域格差があり，都市部向きのシステムになる．また動態 把握でも，高速追従性は一歩 GPS に譲るため，小型，軽 量のメリットを生かした，人の持つ位置情報端末としての 利用が主体と考光られる。表 1 に「PHS 位置情報システ ム」とGPS との比較を示す.

7.おわりに

本解説では，PHSを用いたパーソナルナビゲーション 法の基本原理，弊社が開発している「PHS 位置情報シス テム」の概略説明, GPS 法との比較を行った.

PHS のネットワーク網はまだ都市部中心で広がってい るが，今後リゾート地などに広がることで，スキー場，観 光地等での利用の可能性が大きいシステムと考光られる. また，位置情報の通信方式をより高速化することでの動態 把握速度の向上などの技術を解決することでこれから可能 性を大きく秘めたシステムと考える。 